Published in final edited form as:

Pflugers Arch. 2009 January ; 457(3): 609-622. doi:10.1007/s00424-008-0495-4.

\title{
The gastric HK-ATPase: structure, function, and inhibition
}

\author{
Jai Moo Shin, \\ Department of Physiology, David Geffen School of Medicine, University of California at Los \\ Angeles and VA Greater Los Angeles Healthcare System, Los Angeles, CA 90073, USA \\ Keith Munson, \\ Department of Physiology, David Geffen School of Medicine, University of California at Los \\ Angeles and VA Greater Los Angeles Healthcare System, Los Angeles, CA 90073, USA \\ Olga Vagin, and \\ Department of Physiology, David Geffen School of Medicine, University of California at Los \\ Angeles and VA Greater Los Angeles Healthcare System, Los Angeles, CA 90073, USA

\section{George Sachs \\ Department of Physiology, David Geffen School of Medicine, University of California at Los Angeles and VA Greater Los Angeles Healthcare System, Los Angeles, CA 90073, USA. Membrane Biology, Room 324, Building 113, 11301 Wilshire Boulevard, Los Angeles, CA 90073, USA}

George Sachs: gsachs@ucla.edu

\section{Abstract}

The gastric $\mathrm{H}, \mathrm{K}$-ATPase, a member of the $\mathrm{P}_{2}$-type ATPase family, is the integral membrane protein responsible for gastric acid secretion. It is an $\alpha, \beta$-heterodimeric enzyme that exchanges cytoplasmic hydronium with extracellular potassium. The catalytic $\alpha$ subunit has ten transmembrane segments with a cluster of intramembranal carboxylic amino acids located in the middle of the transmembrane segments TM4, TM5,TM6, and TM8. Comparison to the known structure of the SERCA pump, mutagenesis, and molecular modeling has identified these as constituents of the ion binding domain. The $\beta$ subunit has one transmembrane segment with $\mathrm{N}$ terminus in cytoplasmic region. The extracellular domain of the $\beta$ subunit contains six or seven $\mathrm{N}$ linked glycosylation sites. N-glycosylation is important for the enzyme assembly, maturation, and sorting. The enzyme pumps acid by a series of conformational changes from an $\mathrm{E}_{1}$ (ion site in) to an $\mathrm{E}_{2}$ (ion site out) configuration following binding of MgATP and phosphorylation. Several experimental observations support the hypothesis that expulsion of the proton at $160 \mathrm{mM}(\mathrm{pH} 0.8)$ results from movement of lysine 791 into the ion binding site in the $\mathrm{E}_{2} \mathrm{P}$ configuration. Potassium access from the lumen depends on activation of a $\mathrm{K}$ and $\mathrm{Cl}$ conductance via a KCNQ1/KCNE2 complex and Clic6. $\mathrm{K}$ movement through the luminal channel in $\mathrm{E}_{2} \mathrm{P}$ is proposed to displace the lysine along with dephosphorylation to return the enzyme to the $\mathrm{E}_{1}$ configuration. This enzyme is inhibited by the unique proton pump inhibitor class of drug, allowing therapy of acid-related diseases.

\section{Keywords}

The gastric H,K-ATPase; ATPase structure-function; Proton pump inhibitors; Acid pump antagonists; Gastric acid secretion 


\section{Introduction}

The basis for success of modern methods of therapy of acid secretion has been the identification of unique expression of target proteins by cells like the gastric parietal cell. For example, the major functional location of both the $\mathrm{H} 2$ receptor and the H,K-ATPase is the parietal cell. Histamine binds to the $\mathrm{H} 2$ receptor and stimulates acid secretion through the cAMP-stimulated morphological changes of the parietal cell from the resting status to the stimulated state and activation of the $\mathrm{KCl}$ pathway. The gastric $\mathrm{H}, \mathrm{K}$-ATPase is located in the canaliculus of the stimulated state and secretes gastric acid by an electroneutral ATPdependent hydrogen-potassium exchange [41]. The introduction of $\mathrm{H} 2$ receptor antagonists in 1977 followed by proton pump inhibitors targeted to the gastric H,K-ATPase in 1989 reflected a major medical therapeutic breakthrough in the treatment of peptic ulcers and gastroesophageal reflux disease, resulting in more rapid healing of the lesions and symptom relief $[6,11]$. The $\mathrm{H} 2$ receptor antagonist dramatically increased healing of peptic ulcer disease, but not gastroesophageal reflux disease, which requires greater inhibition of gastric acid secretion that was then achieved by the proton pump inhibitors (PPIs), which inhibit the gastric H,K-ATPase.

The gastric $\mathrm{H}, \mathrm{K}$-ATPase is an $\alpha, \beta$-heterodimeric enzyme. In this review, the structure and function of the H,K-ATPase and inhibitors of this enzyme will be discussed.

\section{Cellular location of the gastric H,K-ATPase}

The gastric H,K-ATPase is found in the parietal cell of the stomach and a small amount in the renal medulla. This enzyme appears to be in cytoplasmic tubular membranes in the resting state and then in the microvilli of the expanded secretory canaliculus in the stimulated state of the parietal cell $[13,45]$. This morphological change is assumed to result from fusion of cytoplasmic vesicles with the rudimentary microvilli to form the elongated microvilli of the expanded secretory canaliculus $[13,45]$. Once the enzyme moves to the canaliculus, the enzyme secrets acid by the exchange of cytoplasmic hydronium with extracellular K. Genomic microarray analysis of genes specifically expressed in a pure (99\%) parietal cell isolate identified the likely K efflux channel associated with the gastric $\mathrm{H}, \mathrm{K}-\mathrm{ATPase}$. The function of this channel is to supply $\mathrm{K}$ to the luminal surface of the pump to allow $\mathrm{H}$ for $\mathrm{K}$ exchange. KCNQ1-KCNE2 were the most highly expressed and significantly enriched members of the large variety of $\mathrm{K}$ channels expressed in the gastric epithelium. The function of this $\mathrm{K}$ channel in acid secretion was then shown by inhibition of secretion in isolated gastric glands with specific KCNQ inhibitors and by co-localization of the channel with the H,K-ATPase in the secretory canaliculus of the parietal cell. KCNQ1KCNE2 appears to be the K efflux channel that is essential for gastric acid secretion [25]. Enrichment of Clic6 appears to identify the necessary accompanying $\mathrm{Cl}$ channel $[29,44]$.

The isolated hog gastric ATPase is obtained in relatively ion tight vesicles and was shown to be a member of the $\mathrm{P}_{2}$-type ATPases where the first step of the reaction is phosphorylation of the catalytic subunit by MgATP with export of protons, and this is followed by luminal $\mathrm{K}$-dependent dephosphorylation and $\mathrm{K}$ reabsorption. This results in electroneutral exchange of cytoplasmic protons for exoplasmic potassium. The hog gastric vesicles as isolated did not include a $\mathrm{KCl}$ pathway and required the addition of ionophores such as nigericin for maximal ATPase activity [41]. Isolation of the ATPase from stimulated rabbit provided evidence for the $\mathrm{K}$ and $\mathrm{Cl}$ conductance pathways [72].

\section{The structure and function of the gastric H,K-ATPase}

The primary structure of the gastric H,K-ATPase $\alpha$ subunits containing the catalytic site was first elucidated in the rat [54] and then in the hog [26], rabbit [4], dog [57], and human [27]. 
This catalytic subunit consists of 1,033 or 1,034 amino acids in length in all species. They are $98 \%$ homologous with each other. Examination of the catalytic subunit revealed that it was highly homologous to the Na, K-ATPase $(\sim 63 \%)$ and less so to the SERCA Ca-ATPase (25\%) [59].

Functional studies demonstrated that ATP catalyzed an electroneutral exchange of $\mathrm{H}$ for K, with a variable stoichiometry of $2 \mathrm{H} / 2 \mathrm{~K} / \mathrm{ATP}$ at $\mathrm{pH} 6.1$ that fell to $1 \mathrm{H} / 1 \mathrm{~K} / \mathrm{ATP}$ as luminal $\mathrm{pH}$ fell to $<3.0[31,37]$.

Later, it was discovered that a second $\beta$ subunit was required for proper maturation and targeting of the enzyme to the apical membrane. This $\beta$ subunit consists of 291 amino acids and contains six or seven $\mathrm{N}$-linked glycosylation sites [40,53,60]. The gastric H,K-ATPase is fully assembled during biosynthesis in the endoplasmic reticulum and delivered to the apical membrane as a hetero-dimeric oligomer. N-glycosylation of the $\beta$ subunit was identified to be responsible for the trafficking. The steady-state distribution of the H,KATPase $\beta$ subunit in polarized cells depends on the balance between (a) direct sorting from the trans-Golgi network, (b) secondary associative sorting with a partner protein, and (c) selective trafficking $[65,67,68]$.

In the $\alpha$ subunit, there is a cluster of intramembranal carboxylic amino acids located in the middle of the transmembrane segments TM4, TM5,TM6, and TM8 that contain the ion binding domain in this enzyme and the $\mathrm{Na}, \mathrm{K}$ - and $\mathrm{Ca}$-ATPases. In the gastric $\mathrm{H}, \mathrm{K}$-ATPase, there is also a lysine 791 located in the fifth transmembrane segment that replaces a serine present in the Na,K-ATPase isoforms. This lysine of the H,K-ATPase seems to characterize the $\mathrm{H}, \mathrm{K}$-enzyme specificity for outward transport of the hydronium ion. A model of the gastric H,K-ATPase operating in the highly acidic secretory canaliculus of the parietal cell is shown in Fig. 1.

The crystal structures of the SERCA ATPase at high resolution by Toyoshima and his collaborators permitted understanding of the catalytic cycle of $\mathrm{P}_{2}$-type enzymes in both general and specific terms [61-63]. Using the crystal structure of the SERCA Ca-ATPase in different conformations as a template, computer-assisted homology modeling and sitedirected mutation analysis resulted in not only an expanded picture of the ion transport mechanism of the enzyme but also explained how the covalently binding PPIs and the $\mathrm{K}^{+}$competitive acid pump antagonists (APAs) inhibited the pump. As a high-resolution crystal structure of the H,K-ATPase has not been described, the exact location of the $\beta$ subunit is not known. It is thought that there is close interaction on the luminal surface with the loop between TM7 and TM8 on the outside of the membrane domain [28] and that perhaps the membrane domain of the $\beta$ subunit is interdigitated between TM9 and TM10 [8,36]. In a crystal of the Na,K-ATPase [30], the $\beta$ subunit membrane domain is tilted and contacts TM7 and TM10, consistent with the yeast two hybrid and biochemical data obtained for the $\mathrm{H}, \mathrm{K}-$ ATPase $[28,50]$. One study, using fluorescence resonance energy transfer, suggested that the $\alpha$ and $\beta$ subunits move toward each other during the E2 to E1 conformational transition [10].

The Na,K- and Ca-ATPases extrude $\mathrm{Na}^{+}$and $\mathrm{Ca}^{2+}$ while utilizing generally the same carboxylic acids as found in the ion binding site of the H,K-ATPase. Given a $\mathrm{p} K_{\mathrm{a}}$ for these carboxyl side chains between 3.0 and 5.0, how does the H, K-ATPase manage to extrude protons at $\mathrm{pH}$ 1.0? As illustrated in Fig. 2, this depends on displacement of one of the bound hydroniums by movement of the $\mathrm{R}-\mathrm{NH}_{3}^{+}$(ammonium) group of lysine 791 into the hydronium binding site $[31,33]$. This movement is generated by the reorientation of the M4 and $\mathrm{M} 6$ helices during the $\mathrm{E}_{1}$ to $\mathrm{E}_{2} \mathrm{P}$ transition and favors stabilization of the hydrogen bonding of the $-\mathrm{R}-\mathrm{NH}_{3}^{+}$of lysine 791 as compared to $\mathrm{H}_{3} \mathrm{O}^{+}$. The entry of $\mathrm{K}^{+}$into the ion 
binding pocket as a focal positive charge would then destabilize the interaction of K791 with glutamyls 795 and 820 and initiate the conversion to the $\mathrm{E}_{1}$ conformation [31].

The postulated displacement of hydronium from site $\mathrm{H} 2$ by Lys791 is strongly supported by the effects of mutating the homologous lysine (Lys800) in the toad bladder H,K-ATPase [7]. This electroneutral proton pump can also transport $\mathrm{Na}^{+}[16]$. However, a $\mathrm{K}^{+}$-stimulated outward current was observed in $\mathrm{Na}^{+}$-loaded oocytes injected with mutants K800A and $\mathrm{K} 800 \mathrm{E}$, showing that loss of the lysine positive charge resulted in $\mathrm{Na}^{+}$outward electrogenic transport. Conversely, the corresponding S782R mutant of the normally electrogenic toad $\mathrm{Na}, \mathrm{K}-\mathrm{ATPase}$ was electroneutral [7]. Thus, it appears that the positively charged side chain in the $\mathrm{Na}, \mathrm{K}-\mathrm{ATPase}$ mutant replaces one $\mathrm{Na}^{+}$in the forward step, making the exchange 2 $\mathrm{Na}^{+}$for $2 \mathrm{~K}^{+}$, and electroneutral and mutation of the positively charged side chain at Lys800 of toad bladder H,K-ATPase allows binding of the third $\mathrm{Na}^{+}$to give $3 \mathrm{Na}^{+}$for $2 \mathrm{~K}^{+}$

exchange generating current. These data strongly support the role of the side chain $\mathrm{NH}_{3}^{+}$ group of Lys791 in ion transport by the H,K-ATPase and its postulated role in the electroneutral mechanism of gastric acid secretion.

The overall general conformational changes of the enzyme are illustrated in Fig. 3. Emphasis is placed on changes occurring in the cytoplasmic domain as the enzyme moves from an $E_{1}$ to an $E_{2}$ configuration following binding of $\mathrm{MgATP}$ and phosphorylation. The crystal structure of the Ca-ATPase has shown that the cytoplasmic domain is divided into three sectors named the $\mathrm{N}$ (nucleotide binding) domain, the A (actuator) domain, and the $\mathrm{P}$ (phosphorylation) domain. Movements induced by ion and ATP binding in these domains are transmitted to the membrane domain to catalyze the ion displacements shown in Fig. 2.

Recently, a paper appeared describing the crystal structure of the SERCA Ca-ATPase in the absence of inhibitors with $\mathrm{BeF}_{3}$ to provide the $\mathrm{E}_{2} \mathrm{P}$ conformation [35]. Homology modeling of the ion site structure of the Ca ATPase compared to the H,K-ATPase is shown in Fig. 4 $[31,33]$. On the left is the ion site region of the SERCA and on the right the H,K ATPase, viewed from the same orientation in the membrane. The replacement of serine 767 with lysine 791 necessitates an expansion of the site and a different orientation of asparagine 792 as compared to asparagine 768 of the Ca pump. The presence of this lysine is essential for proton pumping by the $\mathrm{H}, \mathrm{K}-\mathrm{ATPase}$, with the $\mathrm{R}-\mathrm{NH}_{3}^{+}$residue of the lysine displacing the hydronium ion at the appropriate $\mathrm{p} K_{\mathrm{a}}<1.0$, for outward proton transport.

The functional form of the gastric H,K-ATPase is a $[\alpha \beta]_{2}$ heterodimer oligomer as identified biochemically $[1,48]$. However, the recent crystal structure of the Na,K-ATPase suggests a monomeric heterodimer [30]. The large changes in conformation in the cytoplasmic domain probably accounts for the finding that the enzyme functions as an out of phase oligomeric heterodimer [48]. Thus, when one heterodimer is in the $\mathrm{E}_{1}$ form, the other is obligated to be in the $E_{2}$ from. This has been most clearly demonstrated by measuring the stoichiometry of ATP binding, acid-stable phosphorylation and binding of APAs or PPIs. One mole of ATP binds to $2 \mathrm{~mol}$ of ATPase forming $1 \mathrm{~mol}$ of phosphoenzyme at physiological ATP concentration [48].

The $\mathrm{E}_{1}$ form of the enzyme allows access to the ion binding domain from the cytoplasmic surface and following binding of ATP with two Mg ions, one to stabilize the $\alpha \beta$ orientation of the first two phosphates of the nucleotide and the second in proximity of the acceptor aspartyl residue to allow transfer of the $\gamma$ phosphate to the catalytic subunit of the protein and initiate the change of conformation from the $\mathrm{E}_{1}$ form to the $\mathrm{E}_{1} \mathrm{P}$ conformer with the ion sites binding the hydronium ions. This is followed by conversion to the $\mathrm{E}_{2} \mathrm{P}$ form where the proton is released outward and $\mathrm{K}$ binds from the luminal surface following the path shown 
in Fig. 2. ATP has dual roles in the transport cycle of the gastric H,K-ATPase. ATP phosphorylates the enzyme and promotes the K.E2 $\rightarrow \mathrm{E} 1+\mathrm{K}$ transition [38].

The stoichiometry of protons extruded per ATP has been controversial. Two papers claim a stoichiometry of $2 \mathrm{H}^{+}$at neutral $\mathrm{pH}[37,56]$, another a stoichiometry of 1 [39]. At $\mathrm{pH}>3.0$, two protons can be released in exchange for $2 \mathrm{~K}$ without violating the amount of energy available from ATP hydrolysis, but at $\mathrm{pH}<3.0$, only a single proton can be transported per ATP hydrolyzed.. To explain the variation in stoichiometry, site $\mathrm{H} 3$ can release a proton at neutral $\mathrm{pH}$, but at $\mathrm{pH}<3.0$, this carboxylate in the ion binding domain, site $\mathrm{H} 3$ (E343), remains protonated, whereas site $\mathrm{H} 2$ (E820) is deprotonated due to displacement by Lys 791 , accounting for the change in stoichiometry from 2/ATP to 1/ATP as the luminal $\mathrm{pH}$ decreases. Such a stoichiometric variation is not possible with transport of cations such as $\mathrm{Na}^{+}$by the $\mathrm{Na}, \mathrm{K}-\mathrm{ATPase}$ or $\mathrm{Ca}^{2+}$ by the Ca-ATPases.

The resulting potassium occlusion site from homology modeling [32] showed distorted octahedral geometry with $\mathrm{K}^{+}$bound predominantly on the M4 helix with ligands contributed by backbone carbonyl oxygens of V338, A339, and V341 and by side chain oxygens of E820 and E795. Long duration molecular dynamics (20 ns) after inclusion of explicit water and lipid confirmed the stability of this ion bound conformation (manuscript in preparation). E343 does not participate directly in ion binding in the model but assumed an orientation facing the ion site via interaction with water ( $\mathrm{H} 3$ in Fig. 7a). This arrangement is very similar to the occluded form presented by Swarts et al. [58] with the exception that E343 is predicted to participate in ion binding directly (Fig. 5).

\section{Potassium pathway}

The hydrated model generated for the $\mathrm{E}_{2} \mathrm{P}$ conformation showed a channel for the passage of $\mathrm{K}^{+}$from the luminal vestibule to the ion occlusion site near the middle of the membrane. The M5/M6 loop presents the first protein encounter for passage of the ion into the channel. The only pathway to the site accessed by the ion was between the carbonyl oxygens of L811 and G812 and the sulfur of C813. This led to apparent binding to these two carbonyls (Fig. $7 b$ ) and two molecules of water (not shown). This appears from the model to be the initial entry site into the channel.

At close to neutral $\mathrm{pH}$ with deprotonation of both $\mathrm{E} 820$ and $\mathrm{E} 343$, two $\mathrm{K}^{+}$can bind to provide equal stoichiometry to the two extruded protons. With the absence of deprotonation of E343, the stoichiometry will drop to $1 \mathrm{~K}^{+} / 1 \mathrm{ATP}$ with the initial site of $\mathrm{K}^{+}$occupancy at E820 and E795 and then movement to E343 with reprotonation of E820. Such a model would be consistent with the $\mathrm{K}^{+}$independence of turnover of the E820 mutant [58].

A notable feature of the luminal face of the enzyme modeled in the $E_{2}$ form is the presence of a luminal vestibule bounded by TM4, TM5, and TM6 and the connecting exoplasmic loops between TM3-TM4 and TM5-TM6 containing cysteine 813 as part of the loop between TM5 and TM6. This vestibule would be a natural exit and entry point for transported cations and also provide access to the different classes of inhibitors of the gastric H, K-ATPase and is illustrated in the model of Fig. 2.

\section{The gastric H,K-ATPase as an acid pump}

In 1976, it was shown that gastric acid secretion was due to the action of an electroneutral ATP-dependent hydrogen-potassium exchanger [41]. The H,K-ATPase is the final step of acid secretion, which suggested that an inhibitor of the pump would be more effective in suppressing gastric acid secretion than a receptor antagonist [11]. Accordingly, if inhibition 
of the pump were effective, hormonal stimulation of the parietal cell could not increase gastric acid secretion.

\section{Proton pump inhibitors}

A compound, timoprazole, had been developed in 1975 that inhibited acid secretion irrespective of the nature of the stimulus in vivo whether it was ligands acting via extracellular receptors such as histamine or acetylcholine or the intracellular second messenger, cAMP. This compound is pyridylmethylsulfinyl benzimidazole. It was found that in the absence of acid transport by the ATPase, the compound was relatively ineffective, as was a successor, picoprazole synthesized in 1977. However, when the pump was transporting acid, the compounds did inhibit acid secretion after a lag phase [71]. Subsequently, omeprazole was synthesized and became the first drug of this class to be introduced into clinical use in 1989. Omeprazole ( $\operatorname{Losec}^{\mathrm{r}}$ ) was followed by lansoprazole $\left(\right.$ Prevacid $\left.^{\mathrm{r}}\right)$, pantoprazole (Protonix ${ }^{\mathrm{r}}$ ) or rabeprazole $\left(\right.$ Aciphex $\left.^{\mathrm{r}}\right)$, and more recently by the Senantiomer of omeprazole $\left(\right.$ Nexium $\left.^{\mathrm{r}}\right)$. All of these drugs inhibit the gastric H,K-ATPase by covalent binding, and therefore, the duration of their effect is longer than expected from their levels in the blood [51]. This class of drug has been named PPIs, and these drugs are now the mainstay of treatment of all acid-related diseases. Although they all share a similar mechanism of action, there are subtle chemical differences between them that affect the precise mechanism by which they inhibit the pump, which may result in clinical differences in their effectiveness. The marketed proton pump inhibitors are shown in Fig. 6. An imidazopyridine PPI, tenatoprazole, is in development and differs from the benzimidazole class by having a long plasma half-life [14].

\section{Chemistry of the proton pump inhibitors}

Proton pump inhibitors are weak bases with a $\mathrm{p} K_{\mathrm{a} 1}$ between 3.8 and 4.5 . This weak base $\mathrm{p} K_{\mathrm{a}}$ enables proton pump inhibitors to accumulate in the acidic space of the secretory canaliculus of the stimulated parietal cell. When gastric acid is secreted, the extracellular space of the canaliculus achieves a $\mathrm{pH} \sim 1.0$. This acid space-dependent concentration of the PPIs is the first important property that determines their therapeutic index, giving a concentration at the luminal surface of the pump that is about, 1000-fold of that in the blood.

The second vital step is $\mathrm{pH}$-dependent conversion from the accumulated prodrug to the activated species that is a highly reactive thiophilic reagent. This means that a second protonation of these compounds is required for their activation to the compounds that form disulfides with luminally accessible cysteines of the H,K-ATPase. The order of acid stability is tenatoprazole $>$ pantoprazole $>$ omeprazole $>$ lansoprazole $>$ rabeprazole [49]. Earlier work, which had only considered the chemistry of omeprazole, suggested that the key site that was protonated was the $\mathrm{N}$ of the pyridine moiety, but this would not explain the different rates of activation of the different PPIs with similar pyridine $\mathrm{p} K_{\mathrm{a}} \mathrm{s}$. When the rate of conversion of the different compounds was measured as a function of $\mathrm{pH}$ using $\mathrm{UV}$ absorbance beginning at a relatively neutral $\mathrm{pH}$, rather than with a $\mathrm{pH}$ electrode starting at $\mathrm{pH} 2.0$, in the presence of a large excess of mercaptoethanol, it was found that the $\mathrm{pH}$ dependence of activation reflected protonation of the benzimidazole or pyridoimidazole moiety. The rate of activation of some of the PPIs as a function of medium $\mathrm{pH}$ is shown in Fig. 7. Table 1 shows the two $\mathrm{p} K_{\mathrm{a}} \mathrm{s}$ of all PPIs of Fig. 6 [47].

The actual inhibitory form of these prodrugs is somewhat controversial. In acidic solution, the form that is isolated is on the bottom left of Fig. 8 before reaction with one or more cysteines accessible from the luminal surface of the enzyme, a tetracyclic sulfenamide. This is a planar molecule; thus, any enantiomer of a PPI loses stereo-specifity upon activation. This was assumed for many years to be the actual active form of the drug, but more recent 
data suggest that it is the precursor of the sulfenamide, the hydrated sulfenic acid on the right above the enzyme reaction step that is the reactive species forming directly from the mono-protonated benzimidazole bound on the surface of the pump.

This hypothesis was formulated to explain the reaction with cysteine 813 or cysteine 321 without reaction with cysteine 822; the likely first step is binding of the prodrug protonated on the pyridine part of the compound to the vestibule with cysteine 813 at its apex. With acid transport by the ATPase, the second proton is added, and then the compound can be activated to the sulfenic acid. If this occurs rapidly as for omeprazole or lansoprazole, reaction with cysteine 813 or also 321 takes place, and no drug can access cysteine 822 . However, if the activation is delayed, the drug can access cysteine 822 before activation to the sulfenic acid and then when activated, both cysteine 813 and 822 are derivatized, as has been shown when comparing the cysteines reacting with omeprazole, lansoprazole to those reacting with pantoprazole or tenatoprazole $[49,52]$.

\section{Biology of proton pump inhibitors}

Proton pump inhibitors are prodrugs as discussed above. After accumulation in the stimulated secretory canaliculus of the parietal cell followed binding to the ATPase, the second protonation occurs, and they are then activated to form the thiophilic drug that reacts with luminally accessed cysteines on the pump. It clearly shows acid-catalyzed activation. Hence, it is recommended that they be given $\sim 30$ min before a meal to ensure that the pump is active at peak levels of the drug. It is also necessary to protect them from gastric acid before absorption. Consequently, they are all formulated with an acid-resistant coating that does not dissolve until $\mathrm{pH} \sim 5.0$ to allow access to the duodenum for absorption without destruction by gastric acid. PPIs have the half-life in blood that varies between 60 and 90 min, but because they covalently bind to the pump, their half-life of inhibition of gastric acid secretion is substantially longer than their half-life in blood [43].

Binding sites of proton pump inhibitors-The sites of reaction of the different proton pump inhibitors on the enzyme differs according to the particular proton pump inhibitor. However, all PPIs react with cysteine 813 in the loop between TM5 and TM6, fixing the enzyme in the $\mathrm{E}_{2}$ configuration. This cysteine, as well as cysteines 321 and 822 , is on the direct path from and to the ion binding site as illustrated in Figs. 2 and 3.

Omeprazole reacted with cysteine 813 and 892 , the latter being peripheral to the ion transport domain [5]. Lansoprazole reacted with cysteine 813 and cysteine 321, these being in the luminal vestibule [42], whereas pantoprazole and tenatoprazole react with cysteines 813 and $822[46,49,52]$. The reaction with cysteine 822 confers a rather special property to the covalently inhibited enzyme, namely irreversibility to reducing agents in vitro and in vivo. The binding sites for pantoprazole are shown in Fig. 9 at cysteine 813, as for all the PPIs and cysteine 822 which is a particular property of pantoprazole and tenatoprazole.

Restoration of acid secretion after PPI inhibition-The PPIs are prodrugs, inactive in their native form. The PPIs are rapidly metabolized by the liver. There are no significant adverse effects during treatment with these medications. This may be ascribed to three factors: their ability to accumulate selectively in the highly acidic space of the stimulated secretory canaliculus of the parietal cell due to the $\mathrm{p} K_{\mathrm{a}}$ of the pyridine group of the PPIs, their formation of the reactive cationic (hence relatively membrane impermeable) sulfenic acid on the pump itself, and the requirement for a $\mathrm{pH}<2.5$ for a significant rate of activation.

Because of these properties, these drugs have a very large therapeutic index, but also, as noted previously, the requirement for acid activation results in a delay in their suppression of the pump's activity. Even though meal stimulates acid secretion and acid secretion activates 
PPIs, PPIs cannot inhibit all pumps. About 70\% of pump enzyme is inhibited, as PPIs have short half-life and not all pump enzymes are activated. It takes about 3 days to reach steadystate inhibition of acid secretion, as a balance is struck between covalent inhibition of active pumps, subsequent stimulation of inactive pumps after the drug has been eliminated from the blood, and de novo synthesis of new pumps. The pump protein has a half-life of about 54 $\mathrm{h}$ in the rat [15] (and probably in man); thus, about 20\% new pumps are synthesized over a 24-h period, and it may be that there is greater pump synthesis at night than during the day. In addition, bedtime administration will not add to inhibition of nocturnal acid breakthrough, as the drug will have disappeared by the time nighttime acid secretion is evident. On the assumption that about $70 \%$ of pumps are activated by breakfast and that the PPI is given 30$60 \mathrm{~min}$ before, it can be calculated that steady-state inhibition on once a day dosage is about $66 \%$ of maximal acid output. Increasing the dose has virtually no effect once optimal dosage has been reached, but increasing dose frequency has some effect, so a morning dose and evening dose before meals results in about $80 \%$ inhibition of maximal acid output.

The effect of binding of the drug to cysteine 822 and the direct reversibility of PPI inhibition was examined. A prelude to this analysis was evident in measurement of the halftime of pump protein biosynthesis in rats treated for 7 days with omeprazole $(54 \mathrm{~h}$ in untreated and treated rats) and the halftime of restoration of ATPase activity ( $15 \mathrm{~h}$ ), suggesting a more rapid recovery of ATPase activity and acid secretion than if only de novo biosynthesis was responsible for restoration of ATPase activity [15]. In other experiments, the halftime of restoration of acid secretion in omeprazole-treated rats was $20 \mathrm{~h}[19,70]$. An analysis of the rate of restoration of acid secretion in man after omeprazole inhibition suggested that the halftime was $24 \mathrm{~h}$, whereas after pantoprazole, it was $46 \mathrm{~h}$ [12]. Apparently, only the latter drug gave a rate of recovery compatible with restoration of acid secretion as due entirely to pump turnover $[9,23]$.

To find the difference of inhibitory activity among PPIs, two types of experiments were carried out in rats to further investigate the problem. The animals were stimulated maximally by histamine and a large dose of radiolabel led omeprazole or pantoprazole administered IV, and either the stomach was removed and the ATPase isolated after $2 \mathrm{~h}$ or stomachs were removed at different times after drug administration (1 to $24 \mathrm{~h}$ ), and again the ATPase isolated. Using quantitative Western blot analysis, it was possible to determine the stoichiometry of labeling, and by measuring acid secretion, it was ascertained that about $90 \%$ inhibition had occurred after $1 \mathrm{~h}$.

Then, the isolated enzyme was treated with the endogenous reducing agent, glutathione, that has a concentration of about $3 \mathrm{mM}$ in the parietal cell. As shown in Fig. 10, incubation of the inhibited ATPase with glutathione resulted in a different rate of loss of binding of omeprazole and pantoprazole.

These observations suggest that removal of binding of the drug to cysteine 813 accounts for the fast phase of recovery of acid secretion and the slow recovery occurs because of a delay in removal of the drug from cysteine 822 . Both residues cysteine 813 and 822 are equally labeled by pantoprazole in vivo. The small amount of cysteine 822 bound by omeprazole in vivo is not seen in vitro [51,52], presumably because acidification is isolated gastric vesicles is less than in vivo. In vivo, it is likely that a minor fraction of the omeprazole remains protonated at both the pyridine and benzimidazole nitrogen and is, as for pantoprazole, slowly activated, allowing some access to cysteine 822 .

A similar differential was seen when the time course of labeling was followed by killing the animals at different times and the stoichiometry of labeling determined as shown in Fig. 11. The differential stability of binding of pantoprazole and omeprazole to the ATPase where 
loss of binding was biphasic with each phase having first-order kinetics was shown in Fig. 11. The fast phase accounts for $84 \%$ of omeprazole bound, the slow phase for $16 \%$ of the drug, whereas the fast and slow phases for pantoprazole bound are approximately equal, $51 \%$ and $49 \%$, respectively. These data are again explained by reversibility of almost all of the omeprazole labeling (to cysteine 813 and 892) and only partial reversibility of pantoprazole binding, namely the $51 \%$ bound to cysteine 813 .

The stoichiometry of labeling for full inhibition, namely $2.6 \mathrm{nmol} / \mathrm{mg}$ ATPase protein, reflects the oligomeric nature of the active functional enzyme, as $1 \mathrm{mg}$ of protein contains about $5 \mathrm{nmol}$ of the gastric enzyme. Hence, binding to only half of the enzyme is sufficient for full inhibition.

The above data are consistent with the slower recovery of acid secretion after pantoprazole inhibition as compared to that after omeprazole inhibition deduced from human data [9,23]. Whether this stability of labeling after pantoprazole labeling produces a clinical benefit, particularly in diminishing nocturnal acid breakthrough and night time GERD, remains to be established.

\section{Acid pump antagonists}

An alternative to PPIs is the reversible $\mathrm{K}^{+}$-competitive APAs.

In the early 1980s, it was recognized that several tertiary amines were able to $\mathrm{K}^{+}$ competitively inhibit the H,K-ATPase, and an imidazopyridine compound, SCH28080, was developed for control of acid secretion [22]. In contrast to PPIs, this compound does not require acid secretion to inhibit the enzyme activity [69]. The APAs, including the imidazo[1,2 $\alpha$ ]pyridine, $\mathrm{SCH} 28080$, bind selectively to the $\mathrm{E}_{2} \mathrm{P}$ or $\mathrm{E}_{2}$ form of the enzyme $[48,69]$, and binding to only half cycle was enough to block the enzyme activity [48]. Inhibition by SCH28080 depended on binding of the protonated form of the inhibitor.

In body, unlike the PPIs, inhibition by APAs was expected to be fast and effective, as APAs do not require acid activation which is necessary for PPI activation. However, their duration of action will be determined entirely by their level in the blood, and there will not be the prolongation of inhibition as found in the case of the PPIs where the half-life of the covalent bond is much longer than the half-life of the PPI in the blood. Data in man show the expected rapid and virtually complete inhibition by an APA (PCAB), AZD0865, but a shorter duration of action as compared to S-omeprazole [21]. APAs require bid dosing to show superiority to PPIs but may become the drugs of choice for rapid symptom relief.

As these compounds are reversible, their site of binding cannot be determined simply by identification of the fragment of the ATPase that is labeled, but must rely on the effects of site-directed mutations on the affinity and K-competitive nature of the compound. A key observation was that inhibition by omeprazole and $\mathrm{SCH} 2808$ was mutually exclusive, indicating an overlap in the binding region of these two compounds, and this allowed orientation of the SCH28080 in the same general domain as omeprazole [18]. Site-directed mutations enabled a more exact docking structure for the $\mathrm{K}^{+}$-competitive antagonists that could then be confirmed by varying the structure of the inhibitor and correlating the $K_{\mathrm{i}}$ of such compounds with the docking site model.

Mutations towards the exoplasmic surface of TM4, TM5 [3], TM6, the loop between TM5 and TM6, and one site at the end of TM8 altered either the $K_{\mathrm{i}}$ or changed the nature of inhibition from strictly competitive to mixed or even non-competitive without affecting ion affinity. Mutation of lysine 791 to serine greatly reduced enzyme activity as well as increased the $K_{\mathrm{i}}$ for SCH $28080[31,64,66]$. The latter observations indicate that these 
mutations allow simultaneous occupancy of the inhibitor binding site and the ion binding domain, which does not happen in the wild-type enzyme. These observations are interpreted as showing that the particular mutations generate a space whereby $\mathrm{K}^{+}$can bypass the inhibitor, allowing access to the ion domain situated above the inhibitor binding region.

Using the various mutational data, it was possible to generate a model showing the docking of the imidazonapthyridine to the membrane domain of the H,K-ATPase [32]. This fused ring structure was generated to mimic the calculated structure of the imidazopyridines shown in Fig. 12. The $K_{\mathrm{i}}$ of BYK 36399 was found to be $47 \mathrm{nM}$ similar to the $56 \mathrm{nM}$ determined for $\mathrm{SCH} 28080$. However, when $\mathrm{N}$-methyl group was used to replace the hydrogen of BYK 36399 , the $K_{\mathrm{i}}$ rose to $\sim 1 \mathrm{mM}$. This finding is explained in the model of Fig. 13 where there is interference with binding due to the presence of the methyl group on the nitrogen of the tricyclic structure.

Many APAs with either imidazopyridines or benzimidazole core structures were synthesized. These compounds provided very high affinity to the H,K-ATPase with excellent inhibition $[2,24,55]$. However, despite superior inhibition, developments of many APAs including SCH28080 were dropped because of toxicity. A few APA compounds having other parent structures other than imidazopyridines or benzimidazoles are still being developed. One of these is revaprazan. Revaprazan is a pyrimidine derivative, $N$-(4fluorophenyl)-4,5-dimethyl-6-(1-methyl-1,2,3,4-tetrahydroisoquinolin-2-yl)pyrimidin-2amine hydrochloride. Revaprazan demonstrated dose-dependent inhibition and reached maximal effect at day 1 during the multiple-dose study, which is different from PPIs [17,73]. Revaprazan is now clinically used in the Far East. Another structure of APA is CS-526. CS-526 has the pyrrolopyridazine structure and is also under development [20].

\section{Conclusion}

The gastric H,K-ATPase of the parietal cell pumps acid, which is the final step of gastric acid secretion in the stomach. Stimulation of the parietal cell moves the H,K-ATPase into the secretory canaliculi, and the enzyme then can pump acid by becoming associated with $\mathrm{K}^{+}$and $\mathrm{Cl}^{-}$conductance. One of the stimulants is histamine. Histamine stimulates the enzyme through binding to histamine $\mathrm{H} 2$ receptor. The initial success of H2RAs confirmed that controlling acid secretion enables healing of acid-related diseases. To achieve more effective inhibition, the gastric H,K-ATPase became the rational target, and PPIs were developed. These PPIs provided a major medical success story for the treatment of peptic ulcer disease and GERD.

The gastric H,K-ATPase exchanges hydronium ion with potassium using ATP energy. To transport the hydronium ion, the enzyme undergoes large conformational changes in the transition between $\mathrm{E}_{1} \mathrm{EP}$ and $\mathrm{E}_{2}$. The functional form of the gastric $\mathrm{H}, \mathrm{K}-\mathrm{ATP}$ ase is an oligomeric dimer, $[\alpha \beta]_{2}$. One heterodimer forms $E_{1}$, while the other heterodimer forms $E_{2}$. One mole of the inhibitor per $2 \mathrm{~mol}$ of the enzyme blocks the enzyme reaction. This enzyme is the target of PPIs, the drugs of choice for treatment of acid-related diseases. Covalent inhibitor binding sites, site mutagenesis for analysis of APA binding sites, and homology modeling have provided a framework for understanding of the mechanism of this $\mathrm{P}_{2}$-type ATPase.

\section{References}

1. Abe K, Kaya S, Taniguchi K, Hayashi Y, Imagawa T, Kikumoto M, Oiwa K, Sakaguchi K. Evidence for a relationship between activity and the tetraprotomeric assembly of solubilized pig gastric H/K-ATPase. J Biochem (Tokyo). 2005; 138:293-301. [PubMed: 16169880] 
2. Andersson K, Carlsson E. Potassium-competitive acid blockade: a new therapeutic strategy in acidrelated diseases. Pharmacol Ther. 2005; 108:294-307. [PubMed: 16000224]

3. Asano S, Yoshida A, Yashiro H, Kobayashi Y, Morisato A, Ogawa H, Takeguchi N, Morii M. The cavity structure for docking the $\mathrm{K}(+)$-competitive inhibitors in the gastric proton pump. J Biol Chem. 2004; 279:13968-13975. [PubMed: 14699149]

4. Bamberg K, Mercier F, Reuben MA, Kobayashi Y, Munson KB, Sachs G. cDNA cloning and membrane topology of the rabbit gastric $\mathrm{H}^{+} / \mathrm{K}(+)$-ATPase alpha-subunit. Biochim Biophys Acta. 1992; 1131:69-77. [PubMed: 1316171]

5. Besancon M, Shin JM, Mercier F, Munson K, Miller M, Hersey S, Sachs G. Membrane topology and omeprazole labeling of the gastric $\mathrm{H}^{+}, \mathrm{K}(+)$-adenosinetriphosphatase. Biochemistry. 1993; 32:2345-2355. [PubMed: 8382947]

6. Black JW, Duncan WAM, Durant CJ, Ganellin CR, Parsons ME. Definition and antagonism of histamine H2 receptors. Nature. 1972; 236:385-390. [PubMed: 4401751]

7. Burnay M, Crambert G, Kharoubi-Hess S, Geering K, Horisberger JD. Electrogenicity of Na,K- and $\mathrm{H}, \mathrm{K}-\mathrm{ATPa}$ e activity and presence of a positively charged amino acid in the fifth transmembrane segment. J Biol Chem. 2003; 278:19237-19244. [PubMed: 12637496]

8. Codina J, Li J, Dubose TD Jr. A carboxy-terminus motif of HKalpha2 is necessary for assembly and function. Kidney Int. 2004; 66:2283-2292. [PubMed: 15569317]

9. Dammann HG, Burkhardt F. Pantoprazole versus omeprazole: influence on meal-stimulated gastric acid secretion. Eur J Gastroenterol Hepatol. 1999; 11:1277-1282. [PubMed: 10563540]

10. Dempski RE, Hartung K, Friedrich T, Bamberg E. Fluorometric measurements of intermolecular distances between the alpha- and beta-subunits of the $\mathrm{Na}^{+} / \mathrm{K}^{+}$-ATPase. J Biol Chem. 2006; 281:36338-36346. [PubMed: 16980302]

11. Fellenius E, Berglindh T, Sachs G, Olbe L, Elander B, Sjostrand SE, Wallmark B. Substituted benzimidazoles inhibit gastric acid secretion by blocking $\left(\mathrm{H}^{+}+\mathrm{K}^{+}\right)$ATPase. Nature. 1981; 290:159-161. [PubMed: 6259537]

12. Ferron GM, McKeand W, Mayer PR. Pharmacodynamic modeling of pantoprazole's irreversible effect on gastric acid secretion in humans and rats. J Clin Pharmacol. 2001; 41:149-156. [PubMed: 11210394]

13. Forte JG, Forte TM, Black JA, Okamoto C, Wolosin JM. Correlation of parietal cell structure and function. J Clin Gastroenterol. 1983; 5(Suppl 1):17-27. [PubMed: 6228573]

14. Galmiche JP, Bruley Des Varannes S, Ducrotte P, Sacher-Huvelin S, Vavasseur F, Taccoen A, Fiorentini P, Homerin M. Tenatoprazole, a novel proton pump inhibitor with a prolonged plasma half-life: effects on intragastric $\mathrm{pH}$ and comparison with esomeprazole in healthy volunteers. Aliment Pharmacol Ther. 2004; 19:655-662. [PubMed: 15023167]

15. Gedda K, Scott D, Besancon M, Lorentzon P, Sachs G. Turnover of the gastric $\mathrm{H}^{+}, \mathrm{K}(+)$-adenosine triphosphatase alpha subunit and its effect on inhibition of rat gastric acid secretion. Gastroenterology. 1995; 109:1134-1141. [PubMed: 7557078]

16. Grishin AV, Caplan MJ. ATP1AL1, a member of the non-gastric H,K-ATPase family, functions as a sodium pump. J Biol Chem. 1998; 273:27772-27778. [PubMed: 9774385]

17. Han KS, Kim YG, Yoo JK, Lee JW, Lee MG. Pharmacokinetics of a new reversible proton pump inhibitor, YH1885, after intravenous and oral administrations to rats and dogs: hepatic first-pass effect in rats. Biopharm Drug Dispos. 1998; 19:493-500. [PubMed: 9840211]

18. Hersey SJ, Steiner L, Mendlein J, Rabon E, Sachs G. SCH28080 prevents omeprazole inhibition of the gastric $\mathrm{H}^{+} / \mathrm{K}^{+}$-ATPase. Biochim Biophys Acta. 1988; 956:49-57. [PubMed: 2841979]

19. Im WB, Blakeman DP, Davis JP. Irreversible inactivation of rat gastric $\left(\mathrm{H}^{+}-\mathrm{K}^{+}\right)$-ATPase in vivo by omeprazole. Biochem Biophys Res Commun. 1985; 126:78-82. [PubMed: 2982382]

20. Ito K, Kinoshita K, Tomizawa A, Inaba F, Morikawa-Inomata Y, Makino M, Tabata K, Shibakawa N. Pharmacological profile of novel acid pump antagonist 7-(4-fluorobenzyloxy)-2, 3-dimethyl-1\{[(1S,2S)-2-methyl cyclopropyl]methyl $\}-1 \mathrm{H}-$ pyrrolo [2,3-d] pyridazine (CS-526). J Pharmacol Exp Ther. 2007; 323:308-317. [PubMed: 17630360]

21. Kahrilas PJ, Dent J, Lauritsen K, Malfertheiner P, Denison H, Franzen S, Hasselgren G. A randomized, comparative study of three doses of AZD0865 and esomeprazole for healing of reflux esophagitis. Clin Gastroenterol Hepatol. 2007; 5:1385-1391. [PubMed: 17950677] 
22. Kaminski JJ, Bristol JA, Puchalski C, Lovey RG, Elliott AJ, Guzik H, Solomon DM, Conn DJ, Domalski MS, Wong SC, Gold EH, Long JF, Chiu PJ, Steinberg M, McPhail AT. Antiulcer agents. 1. Gastric antisecretory and cytoprotective properties of substituted imidazo[1,2a]pyridines. J Med Chem. 1985; 28:876-892. [PubMed: 4009611]

23. Katashima M, Yamamoto K, Tokuma Y, Hata T, Sawada Y, Iga T. Comparative pharmacokinetic/ pharmacodynamic analysis of proton pump inhibitors omeprazole, lansoprazole and pantoprazole, in humans. Eur J Drug Metab Pharmacokinet. 1998; 23:19-26. [PubMed: 9625268]

24. Kirchhoff P, Andersson K, Socrates T, Sidani S, Kosiek O, Geibel JP. Characteristics of the K ${ }^{+}$ competitive $\mathrm{H}^{+}, \mathrm{K}^{+}$-ATPase inhibitor AZD0865 in isolated rat gastric glands. Am J Physiol Gastrointest Liver Physiol. 2006; 291:G838-G843. [PubMed: 16798725]

25. Lambrecht NW, Yakubov I, Scott D, Sachs G. Identification of the K efflux channel coupled to the gastric H-K-ATPase during acid secretion. Physiol Genomics. 2005; 21:81-91. [PubMed: 15613615]

26. Maeda M, Ishizaki J, Futai M. cDNA cloning and sequence determination of pig gastric $\left(\mathrm{H}^{+}+\mathrm{K}\right.$ ${ }^{+}$)-ATPase. Biochem Biophys Res Commun. 1988; 157:203-209. [PubMed: 2848518]

27. Maeda M, Oshiman K, Tamura S, Futai M. Human gastric $\left(\mathrm{H}^{+}+\mathrm{K}^{+}\right)$-ATPase gene. Similarity to $\left(\mathrm{Na}^{+}+\mathrm{K}^{+}\right)$-ATPase genes in exon/intron organization but difference in control region. $\mathrm{J}$ Biol Chem. 1990; 265:9027-9032. [PubMed: 2160952]

28. Melle-Milovanovic D, Milovanovic M, Nagpal S, Sachs G, Shin JM. Regions of association between the alpha and the beta subunit of the gastric H,K-ATPase. J Biol Chem. 1998; 273:11075-11081. [PubMed: 9556592]

29. Mizukawa Y, Nishizawa T, Nagao T, Kitamura K, Urushidani T. Cellular distribution of parchorin, a chloride intracellular channel-related protein, in various tissues. Am J Physiol Cell Physiol. 2002; 282:C786-C795. [PubMed: 11880267]

30. Morth JP, Pedersen BP, Toustrup-Jensen MS, Sorensen TL, Petersen J, Andersen JP, Vilsen B, Nissen P. Crystal structure of the sodium-potassium pump. Nature. 2007; 450:1043-1049. [PubMed: 18075585]

31. Munson KB, Gutierrez C, Balaji VN, Ramnarayan K, Sachs G. Identification of an extracytoplasmic region of $\mathrm{H}^{+}, \mathrm{K}(+)$-ATPase labeled by a $\mathrm{K}(+)$-competitive photoaffinity inhibitor. J Biol Chem. 1991; 266:18976-18988. [PubMed: 1655768]

32. Munson K, Vagin O, Sachs G, Karlish S. Molecular modeling of SCH28080 binding to the gastric H,K-ATPase and MgATP interactions with SERCA- and Na,K-ATPases. Ann N Y Acad Sci. 2003; 986:106-110. [PubMed: 12763782]

33. Munson K, Garcia R, Sachs G. Inhibitor and ion binding sites on the gastric H,K-ATPase. Biochemistry. 2005; 44:5267-5284. [PubMed: 15807521]

34. Munson K, Law RJ, Sachs G. Analysis of the gastric H,K ATPase for ion pathways and inhibitor binding sites. Biochemistry. 2007; 46:5398-5417. [PubMed: 17425287]

35. Olesen C, Picard M, Winther AM, Gyrup C, Morth JP, Oxvig C, Moller JV, Nissen P. The structural basis of calcium transport by the calcium pump. Nature. 2007; 450:1036-1042. [PubMed: 18075584]

36. Purhonen P, Thomsen K, Maunsbach AB, Hebert H. Association of renal Na,K-ATPase alphasubunit with the beta-and gamma-subunits based on cryoelectron microscopy. J Membr Biol. 2006; 214:139-146. [PubMed: 17557166]

37. Rabon EC, McFall TL, Sachs G. The gastric [H,K]ATPase: $\mathrm{H}^{+} /$ATP stoichiometry. J Biol Chem. 1982; 257:6296-6299. [PubMed: 6281267]

38. Reenstra WW, Forte JG. H+/ATP stoichiometry for the gastric $\left(\mathrm{K}^{+}+\mathrm{H}^{+}\right)$-ATPase. J Membr Biol. 1981; 61:55-60. [PubMed: 6267286]

39. Reenstra WW, Crothers J Jr, Forte JG. The conformation of H,K-ATPase determines the nucleoside triphosphate (NTP) selectivity for active proton transport. Biochemistry. 2007; 46:10145-10152. [PubMed: 17696364]

40. Reuben MA, Lasater LS, Sachs G. Characterization of a beta subunit of the gastric $\mathrm{H}^{+} / \mathrm{K}(+)-$ transporting ATPase. Proc Natl Acad Sci U S A. 1990; 87:6767-6771. [PubMed: 2168558] 
41. Sachs G, Chang HH, Rabon E, Schackman R, Lewin M, Saccomani G. A nonelectrogenic $\mathrm{H}^{+}$ pump in plasma membranes of hog stomach. J Biol Chem. 1976; 251:7690-7698. [PubMed: 12175]

42. Sachs G, Shin JM, Besancon M, Prinz C. The continuing development of gastric acid pump inhibitors. Aliment Pharmacol Ther. 1993; 7:4-12. discussion 29-31. [PubMed: 8387826]

43. Sachs G, Shin JM, Howden CW. Review article: the clinical pharmacology of proton pump inhibitors. Aliment Pharmacol Ther. 2006; 23(Suppl 2):2-8. [PubMed: 16700898]

44. Sachs G, Shin JM, Vagin O, Lambrecht N, Yakubov I, Munson K. The gastric H,K ATPase as a drug target: past, present, and future. J Clin Gastroenterol. 2007; 41:S226-S242. [PubMed: 17575528]

45. Sawaguchi A, Aoyama F, Ide S, Suganuma T. The cryofixation of isolated rat gastric mucosa provides new insights into the functional transformation of gastric parietal cells: an in vitro experimental model study. Arch Histol Cytol. 2005; 68:151-160. [PubMed: 16276021]

46. Shin JM, Sachs G. Identification of a region of the H,K-ATPase alpha subunit associated with the beta subunit. J Biol Chem. 1994; 269:8642-8646. [PubMed: 8132592]

47. Shin JM, Sachs G. Restoration of acid secretion following treatment with proton pump inhibitors. Gastroenterology. 2002; 123:1588-1597. [PubMed: 12404233]

48. Shin JM, Sachs G. Differences in binding properties of two proton pump inhibitors on the gastric $\mathrm{H}$ ${ }^{+}, \mathrm{K}^{+}$-ATPase in vivo. Biochem Pharmacol. 2004; 68:2117-2127. [PubMed: 15498502]

49. Shin JM, Besancon M, Simon A, Sachs G. The site of action of pantoprazole in the gastric $\mathrm{H}^{+} /$ K(+)-ATPase. Biochim Biophys Acta. 1993; 1148:223-233. [PubMed: 8389196]

50. Shin JM, Cho YM, Sachs G. Chemistry of covalent inhibition of the gastric $\left(\mathrm{H}^{+}, \mathrm{K}^{+}\right)$-ATPase by proton pump inhibitors. J Am Chem Soc. 2004; 126:7800-7811. [PubMed: 15212527]

51. Shin JM, Grundler G, Senn-Bilfinger J, Simon WA, Sachs G. Functional consequences of the oligomeric form of the membrane-bound gastric H,K-ATPase. Biochemistry. 2005; 44:1632116332. [PubMed: 16331993]

52. Shin JM, Homerin M, Domagala F, Ficheux H, Sachs G. Characterization of the inhibitory activity of tenatoprazole on the gastric $\mathrm{H}^{+}, \mathrm{K}^{+}$-ATPase in vitro and in vivo. Biochem Pharmacol. 2006; 71:837-849. [PubMed: 16405921]

53. Shull GE. cDNA cloning of the beta-subunit of the rat gastric H,K-ATPase. J Biol Chem. 1990; 265:12123-12126. [PubMed: 2165052]

54. Shull GE, Lingrel JB. Molecular cloning of the rat stomach $\left(\mathrm{H}^{+}+\mathrm{K}^{+}\right)$-ATPase. J Biol Chem. 1986; 261:16788-16791. [PubMed: 3023364]

55. Simon WA, Herrmann M, Klein T, Shin JM, Huber R, Senn-Bilfinger J, Postius S. Soraprazan: setting new standards in inhibition of gastric acid secretion. J Pharmacol Exp Ther. 2007; 321:866-874. [PubMed: 17369284]

56. Skrabanja AT, Asty P, Soumarmon A, Joep J, de Pont HH, Lewin MJ. $\mathrm{H}^{+}$transport by reconstituted gastric $\left(\mathrm{H}^{+}+\mathrm{K}^{+}\right)$-ATPase. Biochim Biophys Acta. 1986; 860:131-136. [PubMed: 3015212]

57. Song I, Mortell MP, Gantz I, Brown DR, Yamada T. Molecular cloning and structural analysis of canine gastric $\mathrm{H}^{+}, \mathrm{K}(+)$-ATPase. Biochem Biophys Res Commun. 1993; 196:1240-1247. [PubMed: 8250881]

58. Swarts HG, Koenderink JB, Willems PH, Krieger E, De Pont JJ. Asn792 participates in the hydrogen bond network around the $\mathrm{K}^{+}$-binding pocket of gastric H,K-ATPase. J Biol Chem. 2005; 280:11488-11494. [PubMed: 15644331]

59. Sweadner KJ, Donnet C. Structural similarities of Na,K-ATPase and SERCA, the Ca(2+)-ATPase of the sarcoplasmic reticulum. Biochem J. 2001; 356:685-704. [PubMed: 11389677]

60. Toh BH, Gleeson PA, Simpson RJ, Moritz RL, Callaghan JM, Goldkorn I, Jones CM, Martinelli TM, Mu FT, Humphris DC, et al. The 60- to 90-kDa parietal cell autoantigen associated with autoimmune gastritis is a beta subunit of the gastric $\mathrm{H}^{+} / \mathrm{K}(+)$-ATPase (proton pump). Proc Natl Acad Sci U S A. 1990; 87:6418-6422. [PubMed: 1974721]

61. Toyoshima C, Nakasako M, Nomura H, Ogawa H. Crystal structure of the calcium pump of sarcoplasmic reticulum at 2.6 A resolution. Nature. 2000; 405:647-655. [PubMed: 10864315] 
62. Toyoshima C, Asahi M, Sugita Y, Khanna R, Tsuda T, MacLennan DH. Modeling of the inhibitory interaction of phospholamban with the $\mathrm{Ca}^{2+}$ ATPase. Proc Natl Acad Sci U S A. 2003; 100:467-472. [PubMed: 12525698]

63. Toyoshima C, Nomura H, Sugita Y. Crystal structures of $\mathrm{Ca}^{2+}$-ATPase in various physiological states. Ann N Y Acad Sci. 2003; 986:1-8. [PubMed: 12763767]

64. Vagin O, Munson K, Lambrecht N, Karlish SJ, Sachs G. Mutational analysis of the $\mathrm{K}^{+}-$ competitive inhibitor site of gastric H,K-ATPase. Biochemistry. 2001; 40:7480-7490. [PubMed: 11412101]

65. Vagin O, Denevich S, Munson K, Sachs G. SCH28080, a $\mathrm{K}^{+}$-competitive inhibitor of the gastric $\mathrm{H}, \mathrm{K}-\mathrm{ATPase}$, binds near the M5-6 luminal loop, preventing $\mathrm{K}^{+}$access to the ion binding domain. Biochemistry. 2002; 41:12755-12762. [PubMed: 12379118]

66. Vagin O, Denevich S, Sachs G. Plasma membrane delivery of the gastric H,K-ATPase: the role of beta-subunit glycosylation. Am J Physiol Cell Physiol. 2003; 285:C968-C976. [PubMed: 12773316]

67. Vagin O, Turdikulova S, Sachs G. The H,K-ATPase beta subunit as a model to study the role of Nglycosylation in membrane trafficking and apical sorting. J Biol Chem. 2004; 279:39026-39034. [PubMed: 15247221]

68. Vagin O, Turdikulova S, Yakubov I, Sachs G. Use of the H, K-ATPase beta subunit to identify multiple sorting pathways for plasma membrane delivery in polarized cells. J Biol Chem. 2005; 280:14741-14754. [PubMed: 15695513]

69. Wallmark B, Sachs G, Mardh S, Fellenius E. Inhibition of gastric $\left(\mathrm{H}^{+}+\mathrm{K}^{+}\right)$-ATPase by the substituted benzimidazole, picoprazole. Biochim Biophys Acta. 1983; 728:31-38. [PubMed: 6299338]

70. Wallmark B, Larsson H, Humble L. The relationship between gastric acid secretion and gastric $\mathrm{H}$ ${ }^{+}, \mathrm{K}^{+}$-ATPase activity. J Biol Chem. 1985; 260:13681-13684. [PubMed: 2997178]

71. Wallmark B, Briving C, Fryklund J, Munson K, Jackson R, Mendlein J, Rabon E, Sachs G. Inhibition of gastric $\mathrm{H}^{+}, \mathrm{K}^{+}$-ATPase and acid secretion by SCH 28080 , a substituted pyridyl (1,2a)imidazole. J Biol Chem. 1987; 262:2077-2084. [PubMed: 3029064]

72. Wolosin JM, Forte JG. $\mathrm{K}^{+}$and $\mathrm{Cl}^{-}$conductances in the apical membrane from secreting oxyntic cells are concurrently inhibited by divalent cations. J Membr Biol. 1985; 83:261-272. [PubMed: 2582127]

73. Yu KS, Bae KS, Shon JH, Cho JY, Yi SY, Chung JY, Lim HS, Jang IJ, Shin SG, Song KS, Moon BS. Pharmacokinetic and pharmacodynamic evaluation of a novel proton pump inhibitor, YH1885, in healthy volunteers. J Clin Pharmacol. 2004; 44:73-82. [PubMed: 14681344] 


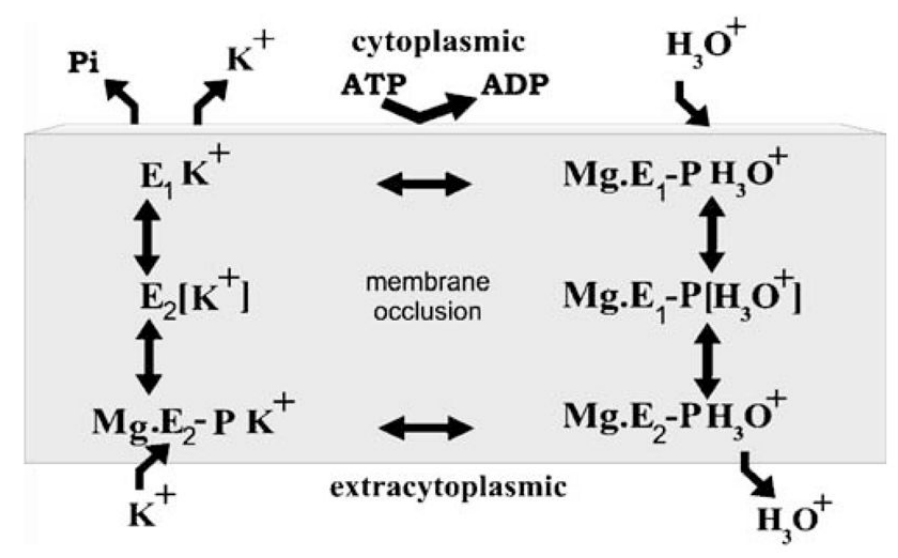

Fig. 1.

The catalytic cycle of the gastric H,K-ATPase. A hydronium ion binds to the cytoplasmic surface of the enzyme, and MgATP phosphorylates the protein at Asp386 to form the first ion transport intermediate in the $\mathrm{E}_{1}$ form. $\mathrm{E}_{1}$ form then converts by a conformational change to the second ion transport form, $\mathrm{E}_{2}$, with the ion site now exposed to the exterior and hydronium is released at $\mathrm{pH} \sim 1.0$. To this form, $\mathrm{K}^{+}$binds from the outside surface to the same region from which the hydronium was released, and the enzyme dephosphorylates, and then $\mathrm{K}^{+}$is trapped within the membrane domain in what was called the occluded form (and a similar form is postulated for the hydronium in the outward step of the cycle). The $\mathrm{K}^{+}$is then de-occluded, allowing reformation of the $E_{1}$ form of the enzyme with the ion site now again facing the cytoplasm, and $\mathrm{K}^{+}$is displaced when ATP is bound. The hydronium ion $\left(\mathrm{H}_{3} \mathrm{O}^{+}\right)$is used instead of the naked $\mathrm{H}^{+}$, as this enables the necessary hydrogen bonding and is more akin to $\mathrm{Na}^{+}$that is transported by the $\mathrm{H}, \mathrm{K}-\mathrm{ATPase}$ at high $\mathrm{pH}$. The above reflects a stoichiometry of $1 \mathrm{H} / 1 \mathrm{~K} / 1 \mathrm{ATP}$ 


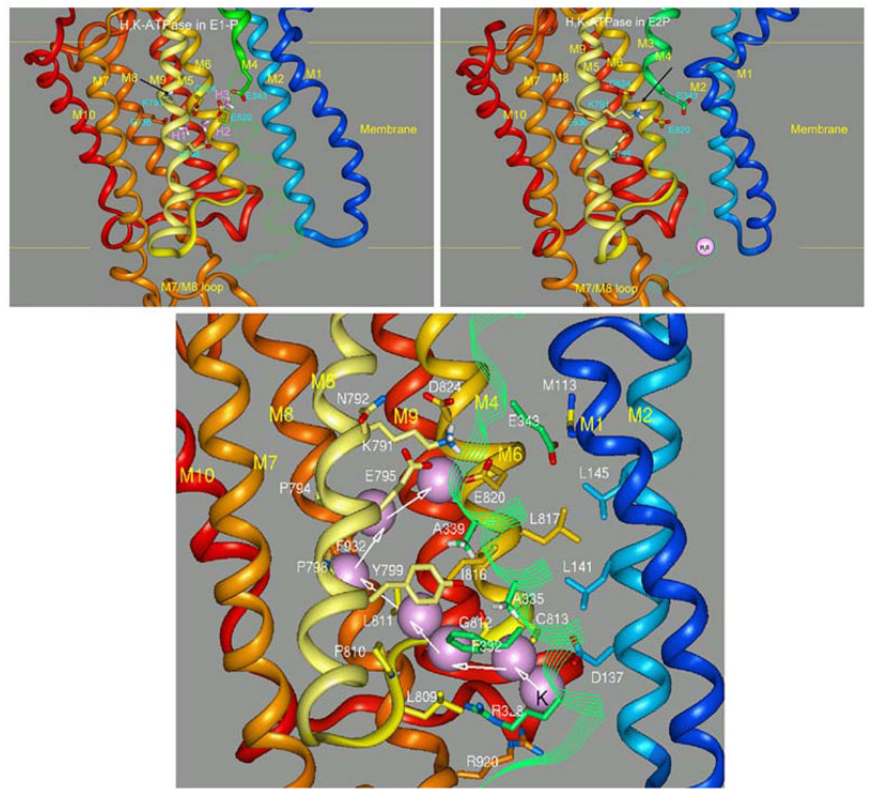

Fig. 2.

Ribbon diagram depicting the ion entry and exit pathways of the gastric H,K-ATPase: The upper left image illustrates the conformation of the pump in the $\mathrm{E}_{1} \mathrm{P}$ form, and the intramembranal carboxylic acids are shown in stick form and numbered in blue, with the arrow highlighting the position of lysine 791. Three hydronium ions are shown in binding sites designated $\mathrm{H} 1, \mathrm{H} 2, \mathrm{H} 3$. The upper right image illustrates the $\mathrm{E}_{2} \mathrm{P}$ conformation where lysine 791 has displaced the hydronium in $\mathrm{H} 2$ to the luminal face, and an arrow now emphasizes the new orientation of lysine 791. Large changes in orientation of the first four transmembrane segments, M1 (dark blue ribbon), M2 (light blue ribbon), M3 and M4 (green ribbon), generate the ion path for hydronium exit and $\mathrm{K}^{+}$entry in $\mathrm{E}_{2} \mathrm{P}$ as well as a luminal vestibule leading to the pathway (bottom of the lower figure). The bottom image illustrates the entry path for $\mathrm{K}^{+}$(illustrated as a series of violet spheres) between M4, M5, $\mathrm{M} 6$, and $\mathrm{M} 8$ in the $\mathrm{E}_{2} \mathrm{P}$ conformation as determined by molecular dynamics simulation (M3 in the foreground is omitted for clarity). The arrival of $\mathrm{K}^{+}$at the top of this path is predicted to destabilize the interaction of lysine 791 with E820 and E795 and initiate the conformational changes leading to release of phosphate at the active site and conversion back to $\mathrm{E}_{1}$. Not shown is the postulated movement of $\mathrm{K}^{+}$into the position of the third hydronium associated with glutamyl 343 before returning to the cytoplasmic face of the enzyme at the top of the respective illustrations 


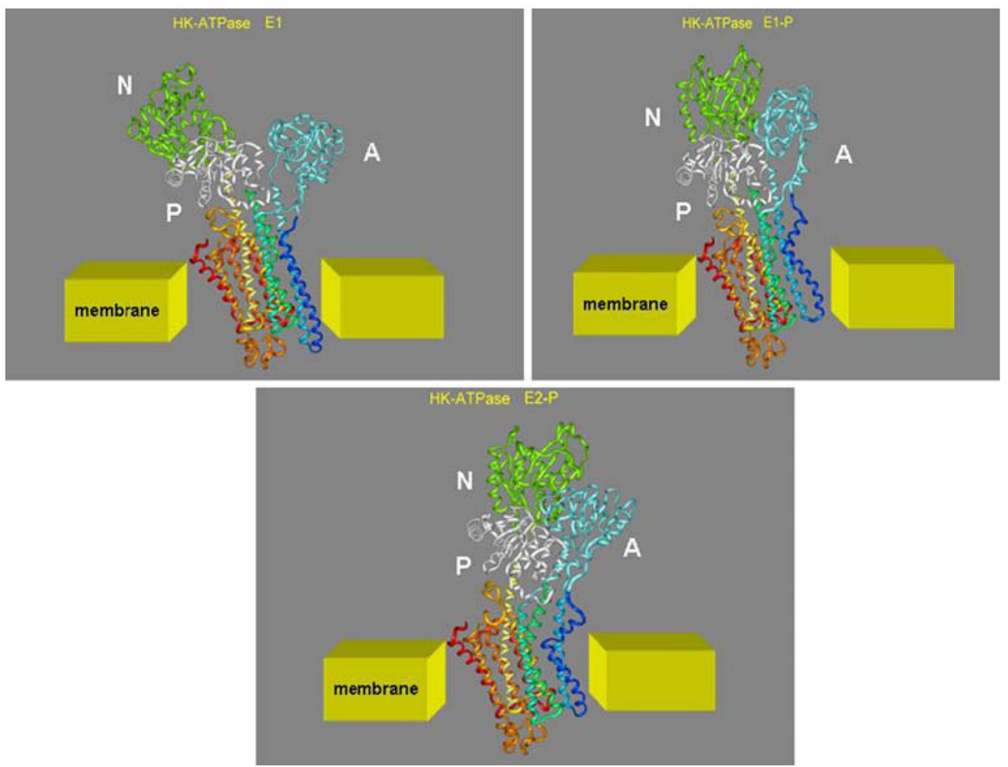

Fig. 3.

General changes in the orientation and shape of the gastric H,K-ATPase in the transition from the $\mathrm{E}_{1}$ to the $\mathrm{E}_{2}$ conformation. On the left is shown the $\mathrm{N}, \mathrm{P}$, and A domains before phosphate transfer from $\mathrm{MgATP}$ where the three cytoplasmic domains change conformation, with the $\mathrm{A}, \mathrm{N}$, and $\mathrm{P}$ domains now closer in the $\mathrm{E}_{1} \mathrm{P}$ form and a further change also in the membrane domain with the formation of the $\mathrm{E}_{2} \mathrm{P}$ form that allows expulsion of a proton into the exoplasmic region to be followed by $\mathrm{K}$ uptake 

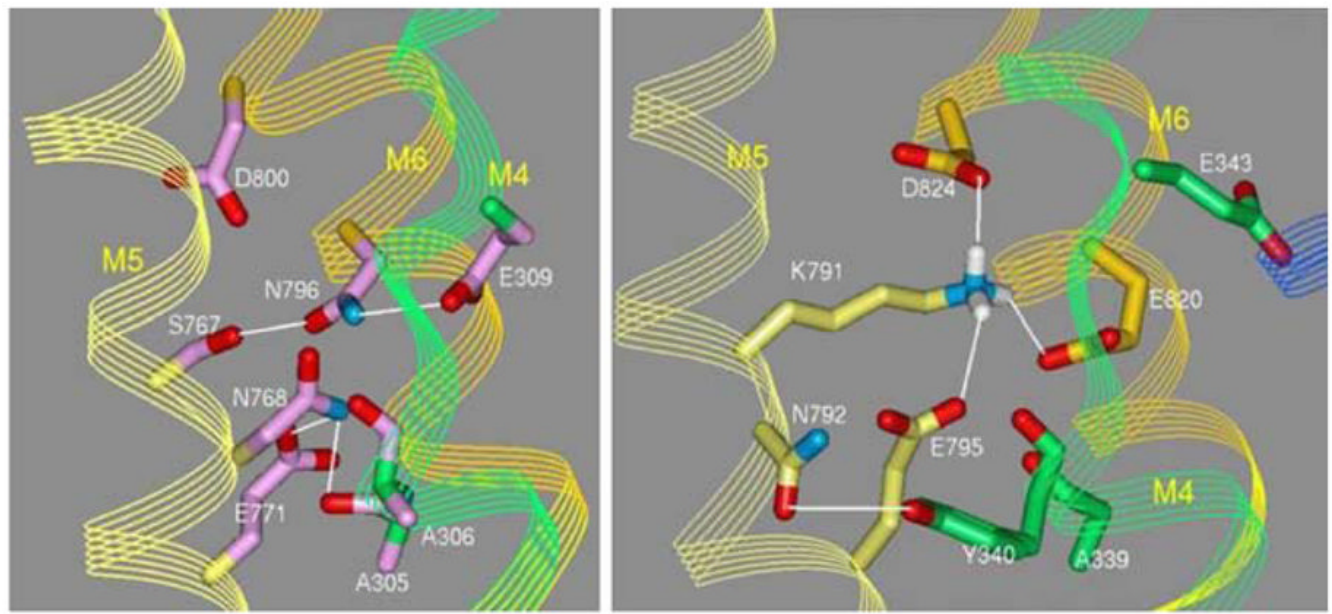

Fig. 4.

A comparison of the ion site structure in $\mathrm{E}_{2} \mathrm{P}$ of the SERCA Ca-ATPase and the gastric $\mathrm{H}, \mathrm{K}$ ATPase showing the need for expansion of the ion site due to the insertion of the $-\mathrm{NH}_{3}^{+}$ group of lysine 791 to energize expulsion of the proton from the $\mathrm{E}_{2} \mathrm{P}$ form of the gastric ATPase 


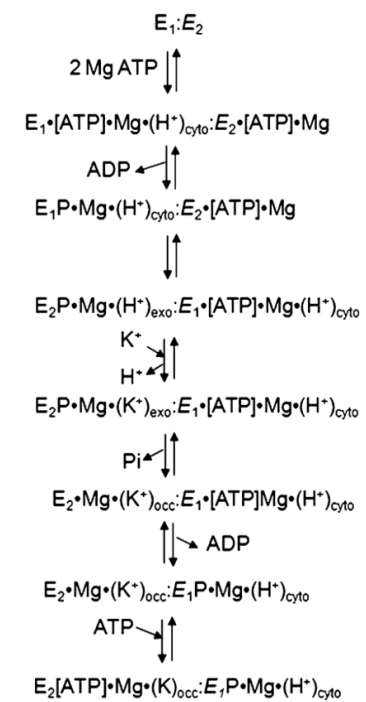

Fig. 5.

The reactions catalyzed by the oligomeric form of the gastric H,K-ATPase where one heterodimer undergoes the cycle from $E_{1}$ to $E_{2}$ as illustrated in Fig. 1, while the other (italics) adopts a reciprocal conformation, i.e., $\mathrm{E}_{2}$ corresponding to $\mathrm{E}_{1}$ and $\mathrm{E}_{1}$ corresponding to $\mathrm{E}_{2}$ in the two out of phase oligomers. One of the heterodimers is italicized 


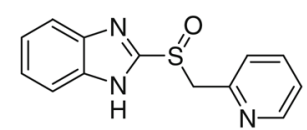

Timoprazole

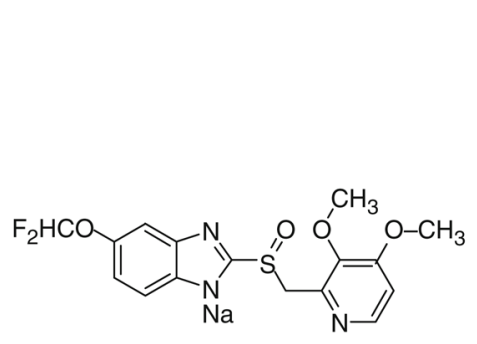

Pantoprazole

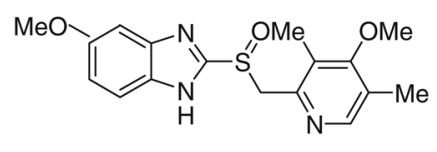

Omeprazole

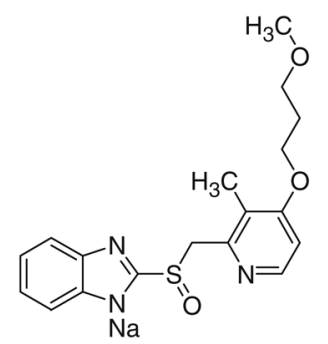

Rabeprazole

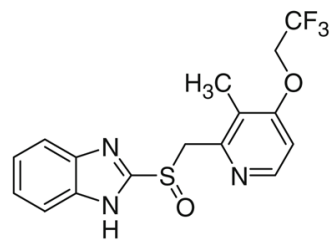

Lansoprazole

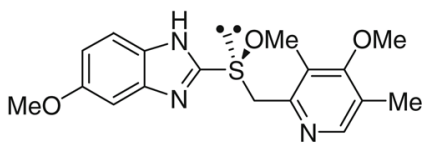

Esomeprazole

Fig. 6.

Different proton pump inhibitors 


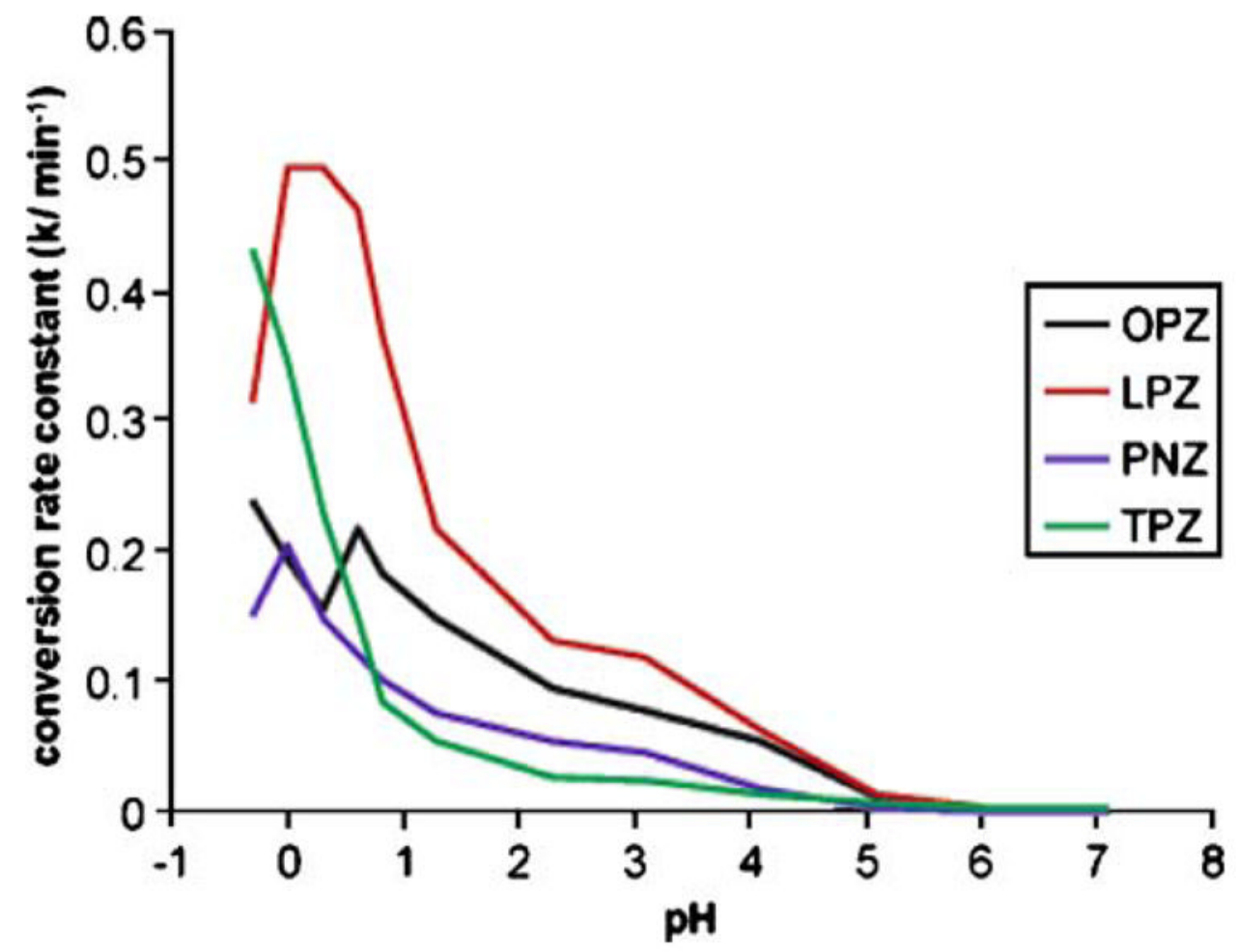

Fig. 7.

The rate constants of activation of the different PPIs as a function of decreasing medium $\mathrm{pH}$. It can be seen that they are slowly activated at a $\mathrm{pH}>3.0$, but then activation increases rapidly at lower $\mathrm{pH}$ values with lansoprazole slightly faster than omeprazole and pantoprazole slightly faster than tenatoprazole but the latter two clearly slower than the former. The rate of activation for lansoprazole decreases at $\mathrm{pH}$ values less than 0 


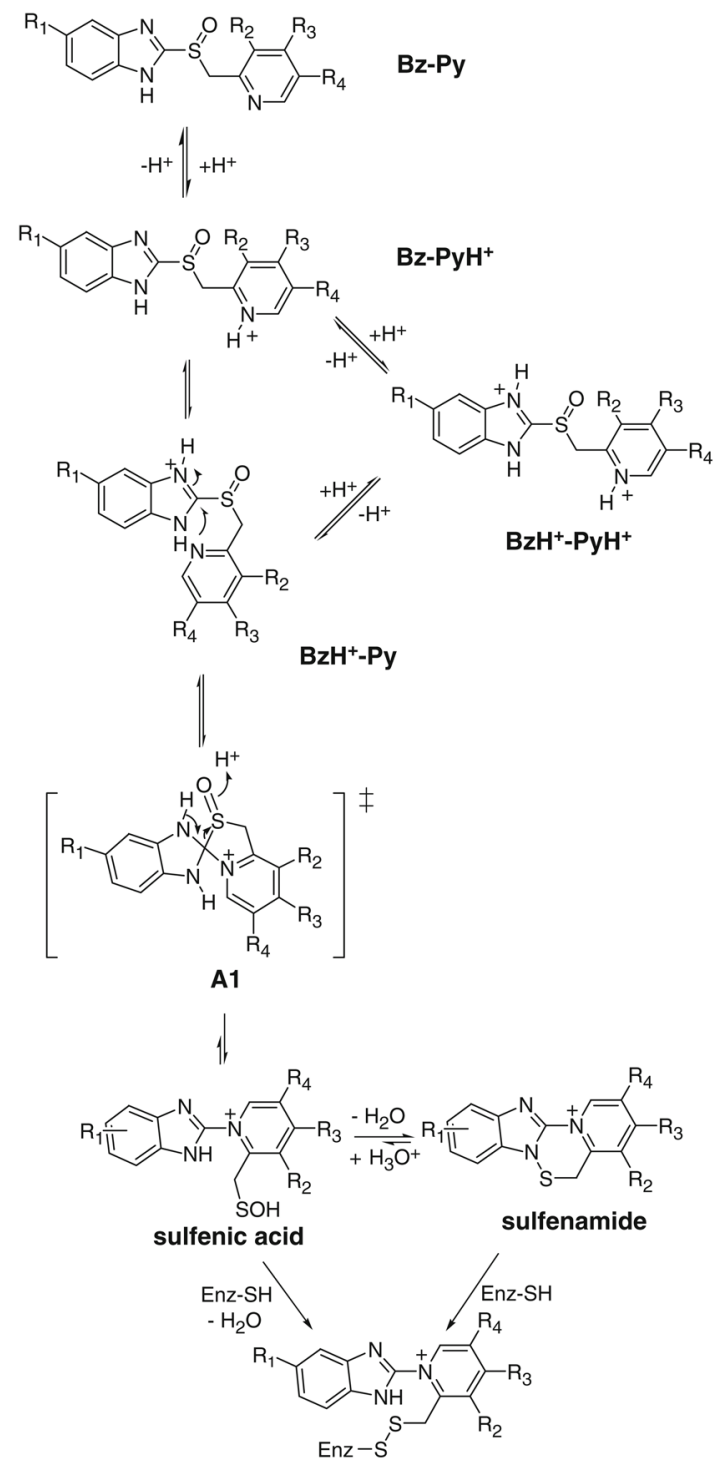

Fig. 8.

The mechanism of activation of the PPIs shown in general structural form. The top of the figure shows the protonation of the pyridine ring, and the second row of structures shows protonation also of the benzimidazole ring. The bis-protonated forms are in equilibrium with the protonated benzimidazole and unprotonated pyridine. In brackets is shown the mechanism of activation whereby the $2 \mathrm{C}$ of the protonated benzimidazole reacts with the unprotonated fraction of the pyridine moiety that results in rearrangement to a permanent cationic tetracyclic sulfenic acid which, in aqueous solute, dehydrates to form a cationic sulfenamide. Either of these thiophilic species can react with the enzyme to form disulfides with one or more enzyme cysteines accessible from the luminal surface of the enzyme 


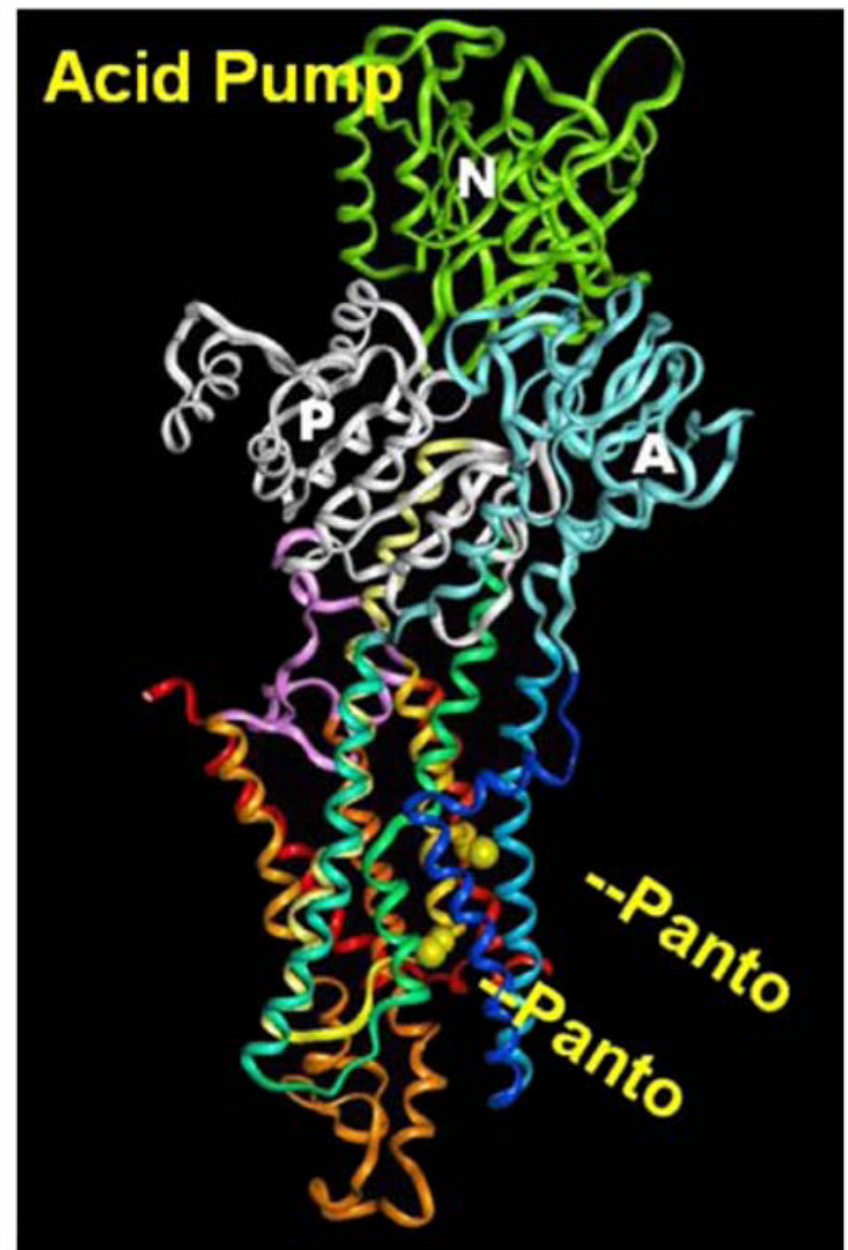

Fig. 9.

The binding sites of pantoprazole to the H,K-ATPase showing one site at cysteine 813 in the vestibule of the pump, and cysteine 8222.5 turns into the membrane domain in TM6 


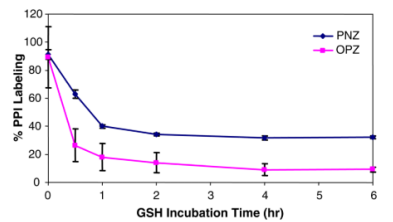

Fig. 10.

The rate of loss of bound PPI (PNZ pantoprazole, OPZ omeprazole) as a function of time of incubation with $10 \mathrm{mM}$ glutathione. The removal of labeled drug is biphasic, the fast phase accounts for about $84 \%$ of omeprazole binding and $60 \%$ of pantoprazole labeling, whereas the slow phase represents about $16 \%$ of omeprazole labeling and $40 \%$ of pantoprazole labeling 


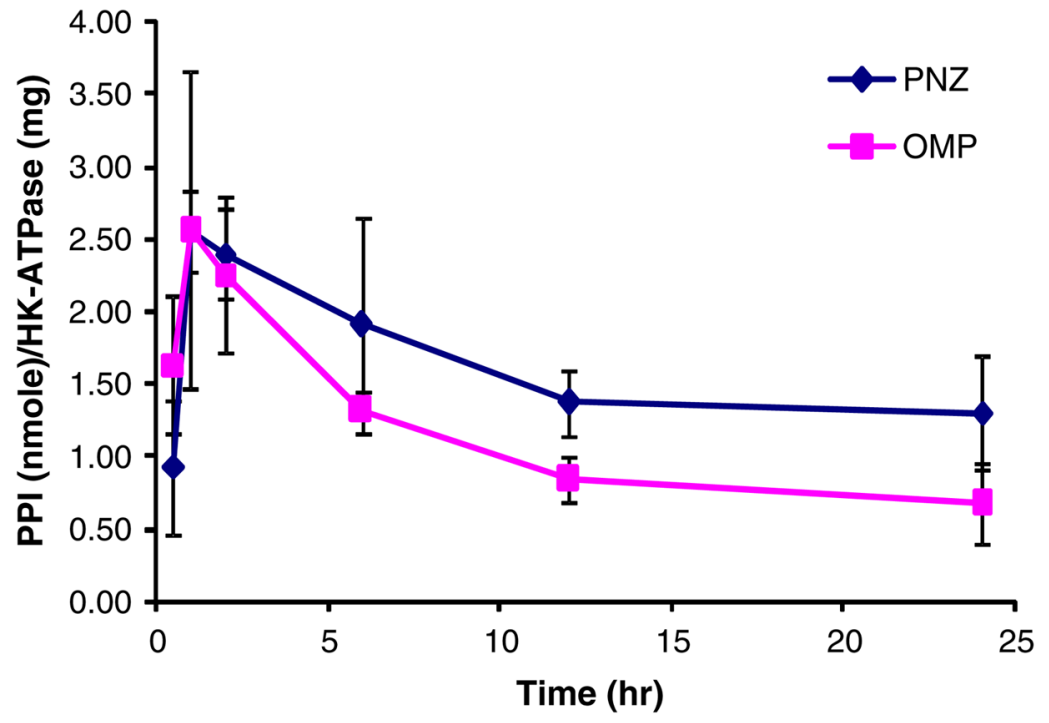

Fig. 11.

The labeling of the ATPase in vivo as a function of time after IV administration of pantoprazole $(P N Z)$ or omeprazole $(O P Z)$. It can be seen that the rate of loss of omeprazole is about twice that of pantoprazole and that the stoichiometry of labeling for almost full inhibition of enzyme is about $2.6 \mathrm{nmol}$ drug bound per milligram $\mathrm{H}, \mathrm{K}$-ATPase. The error bars represent \pm SEM, $n=4-5$ animals in each group 


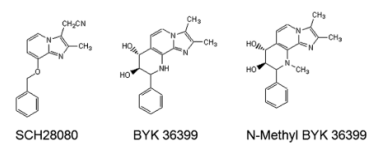

Fig. 12.

Imidazopyridine core structures of some acid pump antagonists 

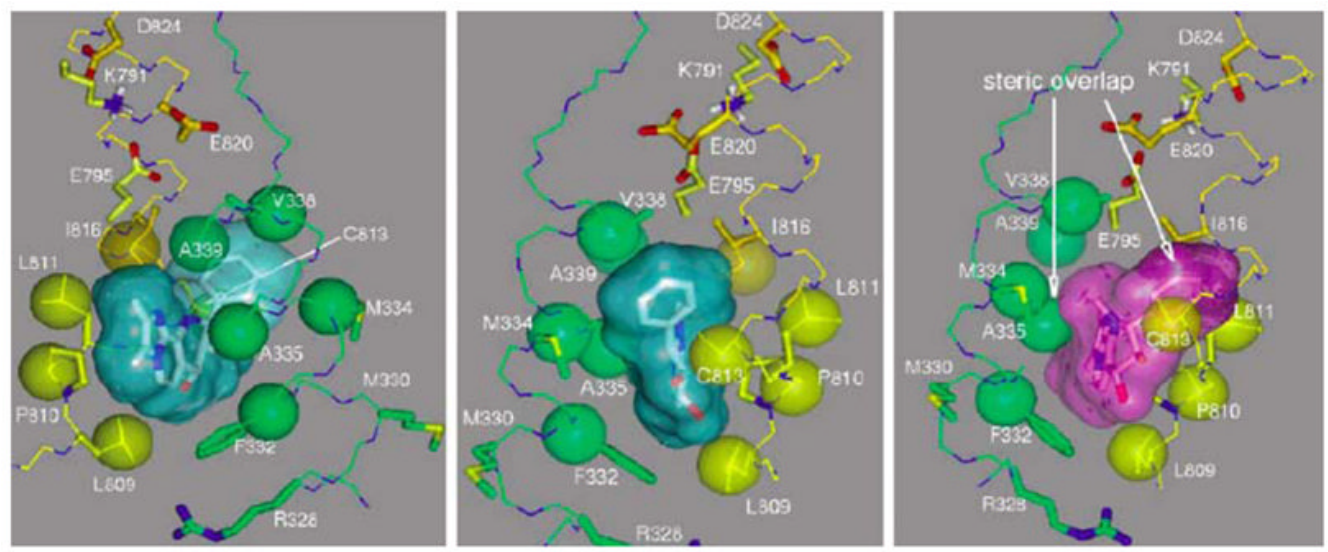

Fig. 13.

Different views of the $\mathrm{K}^{+}$-competitive inhibitor BYK36399 binding site from within the plane of the membrane in the first two images. The residues affecting inhibitor binding in TM4 are shown in green and in the TM5/6 loop are shown in yellow and in TM6 in gold. On the far right is shown the docking of the methylated form, N-methyl BYK36399, where the affinity is much reduced due to steric hindrance (arrows) with Ala 335 and Cys 813. The proximity of Cys 813, a common binding site for the PPIs, to the calculated structure for binding of the APA should be noted. The largest changes in $K_{\mathrm{i}}$ were generated by the mutants Ala335Cys, Phe331Ile, and Leu809Phe. This docking model is also consistent with the binding of an azido derivative of SCH28080 to the region of TM1 and TM2 [31,34] 


\section{Table 1}

$\mathrm{p} K_{\mathrm{a}}$ of the proton pump inhibitors

\begin{tabular}{lrr}
\hline PPIs & $\mathbf{p} \boldsymbol{K}_{\mathrm{a} 1}$ & $\mathbf{p} \boldsymbol{K}_{\mathrm{a} 2}$ \\
\hline Omeprazole & 4.06 & 0.79 \\
Lansoprazole & 3.83 & 0.62 \\
Pantoprazole & 3.83 & 0.11 \\
Rabeprazole & 4.53 & 0.62 \\
Tenatoprazole & 4.04 & -0.12 \\
\hline
\end{tabular}

